\title{
Agreement Between QuantiFERON-TB Gold In-tube and Tuberculin Skin Tests in Hematopoietic Stem Cell Transplantation Candidates
} Hematopoetik Kök Hücre Nakli Adaylarında QuantiFERON-TB Gold In-tube ve Tüberkülin Deri Testi Arasındaki Uyum

\author{
(1) Gülşen iSKENDER ${ }^{1}$, (1) Göknur YAPAR TOROS ${ }^{1}$, (1) Sabahat ÇEKEN ${ }^{1}$, (1) Figen SEZEN ${ }^{2}$, (1) Habip GEDiK ${ }^{3}$, (1) Mehmet Sinan DAL , $^{4}$ \\ (i) Mustafa ERTEK ${ }^{1}$ \\ 1 University of Health Sciences, Dr. Abdurrahman Yurtaslan Ankara Oncology Training and Research Hospital, Clinic of Infectious Diseases and Clinical \\ Microbiology, Ankara, Turkey \\ ${ }^{2}$ Republic of Turkey Ministry of Health, General Directorate of Public Health, Health Threats Early Warning and Response Department, Ankara, Turkey \\ 3istanbul Bakırköy Dr. Sadi Konuk Training and Research Hospital, Clinic of Infectious Diseases and Clinical Microbiology, Istanbul, Turkey \\ 4 University of Health Sciences, Dr. Abdurrahman Yurtaslan Ankara Oncology Training and Research Hospital, Clinic of Hematology, Blood and \\ Marrow Transplantation, Ankara, Turkey
}

\section{Abstract}

Introduction: Malignancies are among the most important risk factors for progression of latent tuberculosis (TB) to active disease. The tuberculin skin test (TST) has been used worldwide for the diagnosis of latent TB. New T-cell-based interferon-gamma release assays such as QuantiFERONTB Gold In-Tube (QFT-GIT) have yielded promising results in this regard, but little information is available on their use in hematopoietic stem cell recipients. The aim of this study was to evaluate the agreement between QFT-GIT and TST in the diagnosis of latent TB in hematopoietic stem cell transplantation (HSCT) candidates.

Materials and Methods: Patients who underwent HSCT in our hospital between November 1, 2013 and July 31, 2015 were retrospectively evaluated from patient files. Those who had both QFT-GIT and TST before transplantation were included in the study. Isoniazid prophylaxis was initiated one week before transplantation and continued for nine months for patients with positive results in one or both tests. The kappa ( $\kappa)$ coefficients were calculated to analyze the agreement between two tests.

Results: The study included 122 patients, (53.3\% autologous and 46.7\% allogeneic hematopoietic stem cell recipients). The median age was 43.5 years (25-75\% IQR: 30-54) and 73\% were men. Bacillus Calmette-Guérin (BCG) scars were seen in 84.4\% of the patients. Tuberculin skin test and QFT-GIT test were positive in $38(31.1 \%)$ and 26 (21.3\%) of the patients, respectively. Both TST and QFT-GIT were positive in 17 patients (13.9\%). There was no statistically significant relationship between the two tests and BCG scars. Statistically significant, fair agreement was found between positive TST and QFT-GIT results $(\kappa=0.37$ and $p<0.001)$. Patients were followed until July 2018 . The median follow-up time of all patients was 39 months (IQR: 10.8-49.0). None of the patients developed active TB during follow-up, but 44.3\% of the patients died due to malignancy and/or opportunistic infections.

Conclusion: Further research is needed to demonstrate the agreement between these two tests in the diagnosis of latent TB in HSCT patients. For now, the combination of these two tests seems to be most rational for these patients.

Keywords: Preventive medicine, purified protein derivative test, prophylaxis, correlation analysis, Mycobacterium tuberculosis

\section{$\ddot{O z}$}

Giriş: Maligniteler latent tüberkülozun (TB) aktif hastalığa ilerlemesinde önemli risk faktörleri arasında yer almaktadır. Tüberkülin deri testi (TDT) latent TB tanısında tüm dünyada yaygın olarak kullanılmaktadır. Yeni T-hücre bazıı interferon-gama salınım testleri, örneğin; QuantiFERON-TB Gold

Cite this article as: İskender G, Yapar Toros G, Çeken S, Sezen F, Gedik H, Dal MS, Ertek M. Agreement Between QuantiFERON-TB Gold In-tube and Tuberculin Skin Tests in Hematopoietic Stem Cell Transplantation Candidates. Mediterr J Infect Microb Antimicrob. 2019;8:20.

Presented in: This study was presented at the EKMUD Congress in 2016 as a poster presentation (11-15 May 2016, Kaya Palazza, Belek, Antalya).

Published: 26 June 2019 
In-Tube (QFT-GIT) bu konuda ümit verici sonuçlar verse de hematopoetik kök hücre alıcılarında (HKHN) kullanımları hakkındaki bilgiler sınırlıdır. Bu çalışmada HKHN adaylarında latent TB tanısında QFT-GIT ile TDT arasındaki uyumun değerlendirilmesi amaçlanmıştır.

Gereç ve Yöntem: Hastanemizde, 1 Kasım 2013-31 Temmuz 2015 tarihleri arasında kök hücre nakli yapılan hastalar retrospektif olarak değerlendirildi. Hastalara ait bilgiler kayıtlı dosyalar vasıtası ile incelendi. Kök hücre nakli öncesi her iki testin yapıldığı hastalar çalışma kapsamına alındı. Testlerden herhangi birinin veya her ikisinin pozitif olması durumunda, nakilden bir hafta önce izoniazid profilaksisi başlandı ve dokuz ay süreyle devam edildi. İki test arasındaki uyumu analiz etmek için kappa (к) katsayıları hesaplandı.

Bulgular: Toplam 122 hasta çalışmaya alındı, (\%53,3'ü otolog ve \%46,7'si allojeneik HKHN alıcıları). Ortanca yaş 43,5 yıl (\%25-75 IQR: 30-54) ve \%73'ü erkekti. Bacillus Calmette-Guérin (BCG) skarı hastaların \%84,4'ünde, pozitif TDT ve OFT-GIT ise sırayla $38(\% 31,1)$ ve $26(\% 21,3)$ hastada tespit edildi. Hastaların 17'sinde (\%13,93) iki test birlikte pozitif idi. Bu iki test ile BCG skar varlığı arasında istatistiksel olarak anlamlı bir ilișki bulunamadı. Pozitif TDT ile QFT-GIT sonuçları arasında istatistiksel olarak anlamlı orta derecede bir uyum saptandı $(\kappa=0,37$ ve $p<0,001)$. Hastalar Temmuz 2018'e kadar takip edildi. Hastaların medyan takip süresi 39 ay (IOR: 10,8-49,0) idi. Hiçbir hastada aktif TB gelişmedi. Bu süreçte hastaların \%44,26'sı malignite ve/veya fırsatçı enfeksiyonlardan dolayı hayatını kaybetti.

Sonuç: HKHN hastalarında latent TB tanısında iki test arasındaki uyumu göstermek için daha ileri araştırmalara ihtiyaç vardır. Şimdilik bu hastalarda iki testin birlikte kullanımı daha rasyonel bir uygulama olarak görünmektedir.

Anahtar Kelimeler: Koruyucu tıp, purified protein derivative testi, profilaksi, korelasyon analizi, Mycobacterium tuberculosis

\section{Introduction}

Tuberculosis (TB) is an old disease that has affected humans for thousands of years ${ }^{[1]}$. It is an infectious disease caused by the bacillus Mycobacterium tuberculosis. It typically affects the lungs (pulmonary TB), but may also affect other organ systems (extrapulmonary TB) ${ }^{[2]}$.Tuberculosis is one of the 10 most fatal diseases worldwide. Millions of people continue to become infected with TB each year. It is estimated that nearly one-third of the world's population have latent $M$. tuberculosis infection. There were an estimated 10 million incident cases of TB (range, 9.0-11.1 million), equivalent to 133 cases (range, 120-148) per 100,000 population globally in 2017 according to the 2018 Global Tuberculosis Report ${ }^{[3]}$. In 2017, TB caused an estimated 1.3 million deaths (range, 1.2-1.4 million) among HIV-negative people and there were an additional 300000 deaths from TB (range, 266,000-335,000) among HIV-positive people. In this report, the estimated TB incidence and mortality rates in Turkey (2017) were 17/100,000 (14-19/100,000) and 0.53/100,000 (0.48-0.59), respectively (including HIV-positives). People with latent TB infection (LTBI) are asymptomatic. Considering that $5-10 \%$ of LTBI may progress to active TB at any time of life, timely identification of $\mathrm{LTBI}$ is important for prevention of progression to active disease. One of the important risk factors for this progression is immunosuppressive states such as HIV infection, malignancies, cancer chemotherapies, and systemic corticosteroid therapy ${ }^{[4,5]}$.

Hematopoietic stem cell transplant (HSCT) recipients are at risk of bacterial, viral, and fungal infections due to their underlying malignancy, chemotherapy regimens, and graftversus-host disease. Tuberculosis is common among these patients, especially in regions with an intermediate-to-high TB burden ${ }^{[6]}$. The incidence of TB in HSCT recipients is reported to range between $0.1 \%$ and $3 \%$, depending on the prevalence of TB in the general population, and is 10-40 times greater than in the general population ${ }^{[7]}$. The mortality rate may be as high as $25 \%$ because of delayed diagnosis and treatment. Identifying individuals with $\mathrm{LTBI}$ in order to prevent progression to active $\mathrm{TB}$ is especially important in allogeneic $\mathrm{HSCT}^{[8]}$. The tuberculin skin test (TST) has been used worldwide for more than a century for diagnosing both LTBI and active TB, but has some limitations such as improper administration of purified protein derivative, cross- reactivity with nontuberculous mycobacteria or Bacillus Calmette-Guérin (BCG) vaccine, and error in measuring the size of induration of the skin reaction. Moreover, its sensitivity in immunocompromised hosts is low due to anergy. The new T-cell-based interferon-gamma release assays (IGRAs), such as QuantiFERON-TB Gold In-Tube (OFT-GIT) and T-SPOT TB tests for diagnosing LTBI have given promising results, but little information is available on their use for the diagnosis of LTBI in HSCT recipients ${ }^{[6,9-11]}$.

In this study, we evaluated the agreement between the QFT-GIT test and TST in the diagnosis of LTBI in HSCT candidates in an oncology educational hospital.

\section{Materials and Methods}

All patients who underwent HSCT in our medical center between November 1, 2013 and July 31, 2015 were retrospectively evaluated. Clinical and laboratory findings of the patients were obtained from follow-up files in the Department of Infectious Disease and Clinical Microbiology and the Department of Blood and Marrow Transplantation. The standard of care at our center is to test these patients for LTBI. Each patient meets with a trained nurse, a hematologist, and an infectious diseases specialist and undergoes evaluation for BCG vaccination status, chest X-ray (CXR), TST, and QFT-GIT at least two weeks before the scheduled HSCT. All patients were informed of the nature of the tests, and their written informed consent was obtained.

In the presence of abnormal CXR or positive TST or QFT-GIT, sputum (if present) acid-fast bacilli smears, culture, and polymerase chain reaction for $M$. tuberculosis and computed tomography scans were performed to rule out active pulmonary TB. 
All patients aged $\geq 18$ years who underwent HSCT for hematological malignancy were included in the study. Patients under 18 years of age and patients with active TB, HIV infection, or immunodeficiency disorders other than hematological malignancy were excluded. The study was approved by the Institutional Review Board of Dr. Abdurrahman Yurtarslan Ankara Oncology Training and Research Hospital (20033663/405722.04.2016). Blood samples were collected from all the patients for QFT-GIT test (Cellestis Limited, Carnegie, Australia) before performing TST to avoid a possible boosting effect of the TST on the QFT-GIT test ${ }^{[12]}$. We used the criteria for positive, negative, and indeterminate results recommended by the manufacturer in QFT-GIT test. The criterion for a positive TST was $\geq 5 \mathrm{~mm}$ induration 48-72 $\mathrm{h}$ after injection. Grades of lymphocytopenia based on absolute lymphocyte counts (ALCs) were assigned according to the common terminology criteria for adverse events: grade 1 : $A L C \geq 800 / \mathrm{mm}^{3}$ to the lower limit of normal; grade 2: $A L C=500-799 / \mathrm{mm}^{3}$; grade $3: A L C=200-499 / \mathrm{mm}^{3}$; and grade 4: $A L C<200 / \mathrm{mm}^{3}$.

In patients with TST $\geq 5 \mathrm{~mm}$ and/or positive QFT-GIT, isoniazid (INH) prophylaxis was initiated 1 week before transplantation and continued for nine months.

\section{Statistical Analysis}

IBM SPSS version 23 statistical program (SPSS IBM, Armonk, NY, USA) was used for statistical evaluations and descriptive information was shown as number and percentage distributions. Kappa (к) coefficients were calculated to analyze the agreement between the TST and QFT-GIT test. Based on these $\kappa$ values, agreement was classified as excellent (0.81-1.00), good (0.61$0.80)$, moderate $(0.41-0.60)$, fair $(0.21-0.40)$, or poor $(0.01-0.20)$ $[6,13]$. A $p$ value of $\leq 0.05$ was considered as statistically significant.

\section{Results}

A total of 122 patients, comprising 65 (53.3\%) autologous and 57 (46.7\%) allogeneic HSCT recipients, were enrolled in the study. The patients' clinical characteristics are shown in Table 1. Median age was 43.5 years (25-75\% IQR: $30-54), 89$ (73\%) were men and $33(27 \%)$ were women. A total of $103(84.4 \%)$ of the patients had BCG vaccination scars. Tuberculin skin test indurations $\geq 5 \mathrm{~mm}$ were seen in 38 of 122 patients (31.1\%). Positive QFT-GIT results were detected in 26 of 122 patients (21.3\%). Both TST and QFT-GIT positivity were detected in 17 of 122 patients (13.9\%).

TST induration was $\geq 5 \mathrm{~mm}$ in $28.2 \%(29 / 103)$ of patients with BCG scar and 47.4\% (9/19) of patients without BCG scar. There was no statistically significant relationship between TST positivity and BCG scars (chi-square test, $p=0.097$ ).
Positive QFT-GIT test was found in 20.4\% (21/103) of patients with BCG scar and 26.3\% (5/19) of patients without BCG scar. No statistically significant relationship was found between QFTGIT positivity and BCG scars (Fisher's Exact test, $\mathrm{p}=0.551$ ).

In comparison of QFT-GIT test with standard TST, QFT-GIT was positive in $44.7 \%$ (17/38) of TST-positive patients (sensitivity). However, this test identified 89.3\% (75/84) of TST-negative patients as negative (specificity) (Table 2). Statistically significant, fair agreement was found between TST (induration size $\geq 5 \mathrm{~mm})$ and QFT-GIT test results $(\kappa=0.37$ and $p<0.001)$ in our patients (Table 2).

Abnormal CXR findings were found in $14(11.5 \%)$ patients, including one with history of adequately treated TB and one with history of inadequately treated TB. None had active TB according to the criteria described in the Materials and Methods section, so were not excluded from the study. Tuberculin skin test $\geq 5 \mathrm{~mm}$ and positive QFT-GIT results were detected in 7 (50\%) and 8 (57.1\%) patients with abnormal CXR, respectively. These differences were not statistically significant.

Table 1. Clinical charactristics of the study population

\begin{tabular}{|c|c|}
\hline Characteristic & $n=122(\%)$ \\
\hline Age (years), median & 43.5 (25-75\% IQR: 30-54) \\
\hline Male gender & $89(73.0)$ \\
\hline Presence of BCG scar & $103(84.4)$ \\
\hline \multicolumn{2}{|l|}{ Type of transplantation } \\
\hline Allogeneic & $57(46.7)$ \\
\hline Autologous & $65(53.3)$ \\
\hline \multicolumn{2}{|l|}{$\begin{array}{l}\text { Underlying hematologic } \\
\text { malignancy }\end{array}$} \\
\hline ALL & $23(18.9)$ \\
\hline AML & $21(17.2)$ \\
\hline $\mathrm{HL}$ & $3(2.5)$ \\
\hline CLL & $2(1.6)$ \\
\hline CML & $2(1.6)$ \\
\hline MDS & $27(22.1)$ \\
\hline MM & $25(20.5)$ \\
\hline \multicolumn{2}{|l|}{ NHL } \\
\hline \multicolumn{2}{|l|}{ Grade of Iymphocytopenia } \\
\hline Grade 1 & $90(73.8)$ \\
\hline Grade 2 & $22(18.0)$ \\
\hline Grade 3 & $9(7.4)$ \\
\hline Grade 4 & $1(0.8)$ \\
\hline TST $(\geq 5 \mathrm{~mm})$ & $38(31.1)$ \\
\hline Positive QFT-GIT & $26(21.3)$ \\
\hline \multicolumn{2}{|c|}{$\begin{array}{l}\text { BCG: Bacille Calmette-Guérin, ALL: Acute lymphoblastic leukemia, AML: Acute myeloid } \\
\text { leukemia, HL: Hodgkin's lymphoma, CLL: Chronic lymphocytic leukemia, CML: Chronic } \\
\text { myeloid leukemia, MDS: Myelodysplastic syndromes, MM: Multiple myeloma, NHL: } \\
\text { Non-Hodgkin lymphoma, TST: Tuberculin skin test, QFT-GIT: QuantiFERON-TB Gold In- } \\
\text { Tube }\end{array}$} \\
\hline
\end{tabular}


Table 2. Analysis of correlation between QuantiFERON-TB Gold In-Tube test and tuberculin skin test in the study population $(n=122)$ by kappa coefficient test

\begin{tabular}{|c|c|c|c|c|c|}
\hline & \multirow[t]{2}{*}{$\mathbf{n}$} & \multirow[t]{2}{*}{$\%$} & \multicolumn{3}{|c|}{ Cohen's $\kappa$ test } \\
\hline & & & $\kappa$ value & $p$ value & Interpretation \\
\hline Sensitivity & $17 / 38$ & 44.7 & \multirow[t]{4}{*}{0.37} & \multirow[t]{4}{*}{$<0.001$} & \multirow[t]{4}{*}{ Fair agreemen } \\
\hline Specificity & $75 / 84$ & 89.3 & & & \\
\hline PPV & $17 / 26$ & 65.4 & & & \\
\hline NPV & $75 / 96$ & 78.1 & & & \\
\hline
\end{tabular}

PPV: Positive predictive value, NPV: Negative predictive value, $\kappa:$ Kappa

Additional subgroup analyses are shown in Table 3. Moderate agreement between the two tests was found for men ( $\kappa=0.45$, $p<0.001$ ), whereas the relationship was not significant for women $(p=0.909)$. Good agreement between the QFT-GIT test and TST was observed in the 40-49 and 60-69 age groups ( $\kappa=0.69, p<0.001$ and $\kappa=0.65, p<0.023$, respectively). There was also moderate agreement in the $20-29$ age group $(\kappa=0.45, p<0.040)$. In the other age groups, there was no statistical relationship between the two tests. Agreement between the two tests was moderate in the presence of BCG scar $(\kappa=0.57, p<0.006)$ and fair in the absence of BCG scar $(\kappa=0.32, p<0.001)$. There was a statistically significant fair to moderate relationship between the two tests only in grade 1 lymphocytopenia $(\kappa=0.42, p=0.001)$. Agreement was moderate in patients with autologous transplantation but fair in allogeneic transplantation $(\kappa=0.43, p<0.001$ vs $\kappa=0.27$, $p<0.030)$. Statistically significant relationship between two tests with moderate agreement was shown in patients with acute myeloid leukemia, multiple myeloma, and non-Hodgkin Iymphoma (Table 3).

Patients were followed until July 2018. The median follow-up period of all patients was 39 months (IQR: 10.8-49.0 months). During the follow-up period, 54 (44.3\%) patients died due to progression of underlying malignancy and/or opportunistic infections. However, active TB did not develop in any patient.

\section{Discussion}

In this study, we have compared the results of the QFT-GIT test and the TST in HSCT candidates in Turkey, a country with intermediate TB burden. We found fair agreement between the two tests in the diagnosis of LTBI in this group of patients.

Despite advances in management and supportive care of patients with HSCT, infections are still reported as the primary cause of death in 8\% of autologous and 17-20\% of allogeneic HSCT recipients. Severe suppression of cellular immunity in HSCT patients increases the risk of mycobacterial as well as viral, bacterial, and fungal infections. The incidence $M$. tuberculosis infection in HSCT recipients varies from $0.0014 \%$ in the USA to $16 \%$ in Pakistan, and was reported as $1.6 \%$ in Spain and
Turkey ${ }^{[14]}$. At least $25 \%$ of $M$. tuberculosis infections in HSCT recipients result from reactivation of $\operatorname{LTBI}^{[15,16]}$.

Clinical and radiological evaluations, microscopy and culture of clinical samples, and molecular assays are still the most important diagnostic tools for active TB. Although there is no "gold standard" test to confirm a diagnosis of LTBI, approximations of sensitivity (true positive) and specificity (true negative) can be made by testing populations with known characteristics ${ }^{[17,18]}$. Because the traditionally used TST exhibits cross-reactivity with nontuberculous mycobacteria or BCG vaccination, the diagnostic sensitivity of TST for active and latent TB may be low in regions such as Turkey that practice routine BCG vaccination. On the other hand, the immunosuppressed state of cancer and HSCT patients may also reduce the sensitivity of TST during the evaluation of immunity due to BCG vaccination or LTBI in these patients by attenuating the TST response ${ }^{[17]}$. Therefore, tests with high specificity and sensitivity are especially necessary for the diagnosis of LTBI in these patients, who may need followup or chemoprophylaxis against TB prior to immunosuppressive treatment and transplantation.

Recently developed T-cell-based IGRAs (e.g., QFT-GIT and T-SPOT) may overcome some of the limitations of TST and can be used as a replacement or adjunct to the TST because they do not crossreact with vaccine strains or nontuberculous mycobacteria ${ }^{[18-20]}$. Since the introduction of IGRAs, an increasing number of studies have examined their performance, specificity, and sensitivity in comparison to TST for the identification of LTBI. However limited data are available regarding the use of IGRAs for testing immunocompromised patients. In a prospective study conducted by Lee et al. ${ }^{[7]}$, IGRA-positive HSCT recipients had a higher risk of progression to active TB than IGRA-negative patients. In the subgroup that underwent both TST and IGRA, none of the TSTpositive HSCT recipients developed TB after transplantation. Their data suggested that IGRA is a more sensitive and specific test for predicting active TB after transplantation than the TST. Many factors interfere with T-cell function and may affect the sensitivity of the IGRA in transplant recipients, including various immunosuppressive drugs, corticosteroids, chemotherapy, and 
Table 3. Agreement between the QuantiFERON-TB Gold In-Tube test and tuberculin skin test according to patient characteristic

\begin{tabular}{|c|c|c|c|c|}
\hline \multirow[t]{2}{*}{ Characteristics } & \multirow[t]{2}{*}{ Subgroups } & \multicolumn{3}{|c|}{ Cohen's $\kappa$ agreement between TST and QFT-GIT } \\
\hline & & Kappa value & p value & Interpretation \\
\hline Gender & Female & 0.20 & ${ }^{*} 0.909$ & \\
\hline \multirow[t]{5}{*}{ Age groups (years) } & **10-19 & - & - & \\
\hline & $20-29$ & 0.45 & 0.040 & Moderate agreement \\
\hline & $40-49$ & 0.69 & 0.001 & Good agreement \\
\hline & $50-59$ & 0.27 & ${ }^{*} 0.102$ & \\
\hline & $60-69$ & 0.65 & 0.023 & Good agreement \\
\hline \multirow[t]{2}{*}{ BCG scars } & Present & 0.57 & 0.006 & Moderate agreement \\
\hline & Absent & 0.32 & $<0.001$ & Fair agreement \\
\hline \multirow{2}{*}{ Lymphocytopenia } & Grade 3 & 0.36 & ${ }^{*} 0.284$ & \\
\hline & ${ }^{* *}$ Grade 4 & - & - & \\
\hline \multirow[t]{2}{*}{ Type of transplantation } & Allogeneic & 0.27 & 0.030 & Fair agreement \\
\hline & Autologous & 0.43 & $<0.001$ & Moderate agreement \\
\hline \multirow[t]{4}{*}{ Underlying hematological malignancy } & ALL & 0.09 & ${ }^{*} 0.656$ & \\
\hline & AML & 0.53 & 0.004 & Moderate agreement \\
\hline & $\mathrm{HL}$ & 0.08 & ${ }^{*} 0.694$ & \\
\hline & ${ }^{* *} \mathrm{CLL}$ & - & - & \\
\hline
\end{tabular}

${ }^{*}$ Not statistically significant.

${ }^{*}$ Could not be evaluated due to small sample size.

BCG: Bacille Calmette-Guérin, ALL: Acute lymphoblastic leukemia, AML: Acute myeloid leukemia, HL: Hodgkin's lymphoma, CLL: Chronic lymphocytic leukemia, CML: Chronic myeloid leukemia, MDS: Myelodysplastic syndromes, MM: Multiple myeloma, NHL: Non-Hodgkin lymphoma, TST: Tuberculin skin test, QF-GIT: QuantiFERON-TB Gold In-Tube, K: Kappa

the hematologic disease itself ${ }^{[21]}$. In a study of patients with rheumatic disease planned to receive tumor necrosis factor- $\alpha$ blocking agents, the specificity of QFT-GIT was $85.7 \%$ and sensitivity was $73.9 \%$. The authors concluded that QFT-GIT was a useful alternative to TST for the diagnosis of LTBI due to its specificity and sensitivity ${ }^{[22]}$. We compared the OFT-GIT test with standard TST in this regard and found that in comparison to TST results, the QFT-GIT test showed higher specificity than sensitivity (89.3\% vs 44.7\%) (Table 2).

Published comparisons have not reported consistent agreement between QFT-GIT and TST results in persons with immunosuppressive conditions other than HIV infection. A study from Turkey that analyzed the performance of the TST and QFT-GIT in hemodialysis patients demonstrated fair to moderate agreement between the two tests in both $B C G$ vaccinated and non-vaccinated patients. The authors suggested that the two tests could be used concurrently for LTBI screening ${ }^{[23]}$. In a study comparing QFT-GIT and TST for the detection of LTBI among patients with systemic lupus erythematosus, the agreement between OFT-GIT and TST $(\geq 5 \mathrm{~mm})$ was $64.4 \%(\kappa=0.33)^{[24]}$. Studies conducted on patients with hematological malignancy and HSCT recipients suggested that IGRAs may be more useful screening tests for $\mathrm{LTBI}$ and active TB than TST ${ }^{[25]}$. One prospective study conducted in South Korea (with intermediate TB burden) compared QFT-GIT with TST for detecting LTBI prior to HSCT and found a slightly higher tendency for TB development after HSCT with positive QFT-GIT (2.80 per 100 person-years) than in those with positive TST outcomes (0 per 100 person-years). 
This difference was not statistically significant. The authors recommended examining all patients with both modalities in addition to other clinical criteria for LTBI (e.g., old TB lesions on CXR images, history of inadequate TB treatment, recent TB exposure) as the safest way to detect LTBI in HSCT recipients ${ }^{[6]}$. In our study, TST $\geq 5 \mathrm{~mm}$ was found in $28.2 \%$ of patients with BCG scar and in $47.4 \%$ of patients without scar. Although this discrepancy may be due to the immunosuppressive state of the patients, differences were not statistically significant (chi-square test, $\mathrm{p}=0.097$ ). QFT-GIT positivity was not obviously different in patients with and without BCG scars $(20.4 \%$ vs $26.3 \%$, Fisher's Exact test, $\mathrm{p}=0.551$ ).

A systematic review of clinical practice guidelines for the screening and prevention of LTBI in immunosuppressed patients reported that based on the low sensitivity of TST in immunosuppressed patients, some guidelines suggest a twostage screening using IGRA and TST to increase LTBI detection rates. In all guidelines, an individual was considered at risk for LTBI if either TST or IGRA was positive. It has been shown that IGRA generally performs better than TST among patients who are immunosuppressed and had previously been vaccinated with BCG. Either a positive TST or IGRA was considered to be a sufficient evidence of LTBI once active TB was excluded by further evaluations. Latent TB infection treatment was recommended in this setting ${ }^{[26]}$.

Considering the epidemiology of TB in Turkey and the immune status of our patients, we considered treatment of LTBI in TSTor QFT-GIT-positive patients before HSCT. Isoniazid prophylaxis against LTBI was shown to reduce active infection development by $75-90 \%$ and has been successfully used for this purpose in HSCT recipients. In geographical locations where TB is prevalent, pre-and post-HSCT follow-up for TB and the use of INH prophylaxis should be seriously considered ${ }^{[27-29]}$. We gave INH prophylaxis to patients with TST $\geq 5 \mathrm{~mm}$ and/or positive QFT-GIT as markers of LTBI before HSCT. None of our patients developed active TB during follow-up. We believe that this is largely due to INH prophylaxis in TST and/or QFT-GIT positive cases.

In a study in Zambia involving 112 persons with active TB (HIVpositive and negatives), QFT-GIT and TST were significantly less sensitive in persons infected with HIV than in persons not infected with HIV. In these patients, low CD4 counts were associated with increases in false-negative TST results and indeterminate and false-negative QFT-GIT results ${ }^{[30]}$. In a study from Turkey conducted by Çavuşoğlu et al. ${ }^{[31]}$, QFT-GIT rates were found to be 0.33-0.62 times less positive in patients with hematological malignancy and other immunodeficiency conditions affecting the cellular immune response compared to the immunocompetent group. We found moderate agreement between the two tests only in patients with grade 1 lymphocytopenia; there was no significant relationship between the two tests in other grades of lymphocytopenia in our study.

In Çavuşoğlu et al.'s ${ }^{[31]}$ study, the agreement between QFT-GIT and TST was $71.3 \%$ for positive and $75.5 \%$ for negative cases. The highest agreement was in the 35-64 age group ${ }^{[31]}$. We found good agreement between the two tests in the 40-49 and 60-69 age groups.

Important limitations of our study are the small number of patients and the provision of INH prophylaxis to both groups, which precluded comparison of the two tests' predictive value in terms of active TB development following HSCT.

\section{Conclusion}

To the best of our knowledge, there is no previous study evaluating agreement between TST and IGRAs in HSCT candidates in Turkey. Further and larger studies are needed to demonstrate agreement between the two tests or the superiority of one of them in the detection of LTBI in HSCT candidates. For now, the combination of these two tests together with risk assessment, radiography, and other medical and diagnostic evaluations seems to be the most rational approach to diagnosing LTBI.

\section{Ethics}

Ethics Committee Approval: The study was approved by the Institutional Review Board of Dr. Abdurrahman Yurtarslan Ankara Oncology Training and Research Hospital (20033663/405722.04.2016).

Informed Consent: All patients were informed of the nature of the tests, and their written informed consent was obtained.

Peer-review: Externally and internally peer-reviewed.

\section{Authorship Contributions}

Surgical and Medical Practices: G.I., G.Y.T., S.Ç., M.S.D., Concept: G.I., G.Y.T., S.Ç., M.E., Design: G.I., G.Y.T., S.Ç., M.E., Data Collection or Processing: G.I., S.Ç., M.S.D., Analysis or Interpretation: G.I., G.Y.T., F.S., H.G., Literature Search: G.I., G.Y.T., S.Ç., Writing: G.I.

Conflict of Interest: No conflict of interest was declared by the authors.

Financial Disclosure: The authors declared that this study received no financial support.

\section{References}

1. Hershkovitz I, Donoghue HD, Minnikin DE, May H, Lee OY, Feldman M, Galili E, Spigelman M, Rothschild BM, Bar-Gal GK. Tuberculosis origin: the Neolithic scenario. Tuberculosis (Edinb). 2015;95(Suppl 1):122-6.

2. Qian $X$, Nguyen DT, Lyu J, Albers AE, Bi X, Graviss EA. Risk factors for extrapulmonary dissemination of tuberculosis and associated mortality during treatment for extrapulmonary tuberculosis. Emerg Microbes Infect. 2018;7:102. 
3. World Health Organization (WHO). Last accessed date: 2018 September 18. Available from: https://www.who.int/tb/publications/global_report/en

4. Vynnycky E, Fine PE. Lifetime risks, incubation period, and serial interval of tuberculosis. Am J Epidemiol. 2000;152:247-63.

5. Auguste P, Tsertsvadze A, Pink J, Court R, McCarthy N, Sutcliffe P, Clarke A. Comparing interferon-gamma release assays with tuberculin skin test for identifying latent tuberculosis infection that progresses to active tuberculosis: systematic review and meta-analysis. BMC Infect Dis. 2017;17:200.

6. Moon SM, Lee SO, Choi SH, Kim YS, Woo JH, Yoon DH,Suh C, Kim DY, Lee JH, Lee JH, Lee KH, Kim SH. Comparison of the QuantiFERON-TB Gold InTube test with the tuberculin skin test for detecting latent tuberculosis infection prior to hematopoietic stem cell transplantation. Transpl Infect Dis. 2013;15:104-9.

7. Lee YM, Lee SO, Choi SH, Kim YS, Woo JH, Kim DY, Lee JH, Lee JH, Lee $\mathrm{KH}, \mathrm{Kim} \mathrm{SH}$. A prospective longitudinal study evaluating the usefulness of the interferon-gamma releasing assay for predicting active tuberculosis in allogeneic hematopoietic stem cell transplant recipients. J Infect. 2014;69:165-73.

8. de la Camara R, Martino R, Granados E, Rodriguez-Salvanes FJ, Rovira M, Cabrera R López J, Parody R, Sierra J, Fernández-Rañada JM, Carreras E. Tuberculosis after hematopoietic stem cell transplantation: incidence, clinical characteristics and outcome. Spanish Group on Infectious Complications in Hematopoietic Transplantation. Bone Marrow Transplant. 2000;26:291-8.

9. Kim SH, Lee SO, Park JB, Park IA, Park SJ, Yun SC, Jung JH, Kim YH, Kim SC, Choi SH, Jeong JY, Kim YS, Woo JH, Park SK, Park JS, Han DJ. A prospective longitudinal study evaluating the usefulness of a T-cell-based assay for latent tuberculosis infection in kidney transplant recipients. Am J Transplant. 2011;11:1927-35.

10. Park KH, Cho OH, Ko KB, Lee $Y$, Park HJ, Park SY, Moon SM, Chong YP, Lee SO, Choi SH, Kim YS,Woo JH, Kim SH. Serial testing of T-SPOT.TB assays with anti-tuberculosis therapy in patients with extrapulmonary tuberculosis. Infect Chemother. 2011;43:245-50.

11. Moon SM, Park IA, Kim SM, Park SJ, Jung JH, Kim YH, Park JB, Hong B, Lee SO, Choi SH, Kim YS, Woo JH, Park SK, Lee SK, Park JS, Han DJ, Kim $\mathrm{SH}$. Living donor and recipient screening for latent tuberculosis infection by tuberculin skin test and interferon-gamma releasing assay in a country with an intermediate burden of tuberculosis. J Infect Chemother. 2013;19:1009-13.

12. van Zyl-Smit RN, Pai M, Peprah K, Meldau R, Kieck J, Juritz J, Badri M, Zumla A, Sechi LA, Bateman ED, Dheda K. Within-subject variability and boosting of T-cell interferon-gamma responses after tuberculin skin testing. Am J Respir Crit Care Med. 2009;180:49-58.

13. Landis JR, Koch GG. The measurement of observer agreement for categorical data. Biometrics. 1977;33:159-174.

14. Al-Anazi KA, Al-Jasser AM, Alsaleh K. Infections caused by Mycobacterium tuberculosis in recipients of hematopoietic stem cell transplantation Front Oncol. 2014;4:231.

15. Garcia-Elorriaga G, del Rey-Pineda G. Tuberculosis and hematopoietic stem cell transplant: review of a difficult and often underestimated problem. World J Clin Infect Dis. 2013;3:70-8.

16. Maeda T, Kusumi E, Kami M, Kawabata M, Le Pavoux A, Hara S, Chizuka A, Murashige N, Tanimoto TE, Matsumura T, Yuji K, Wake A, Miyakoshi S, Morinaga S, Taniguchi S; Tokyo Stem Cell Transplant (SCT) Consortium.
Disseminated tuberculosis following reduced-intensity cord blood transplantation for adult patients with hematological diseases. Bone Marrow Transplant. 2005;35:91-7.

17. Moon HW, Hur M. Interferon-gamma Release Assays for the Diagnosis of Latent Tuberculosis Infection: an Updated Review. Ann Clin Lab Sci. 2013:43:221-9.

18. Updated Guidelines for Using Interferon Gamma Release Assays to Detect Mycobacterium tuberculosis Infection - United States, Morbidity and Mortality Weekly Report. 2010;59:5.

19. Mazurek GH, Villarino ME. Guidelines for using the QuantiFERON-TB test for diagnosing latent Mycobacterium tuberculosis infection. MMWR. 2003;52:15-8.

20. Andersen $P$, Munk ME, Pollock JM, Doherty TM. Specific immune-based diagnosis of tuberculosis. Lancet. 2000;356:1099-104.

21. Sester U, Wilkens $H$, van Bentum $K$, Singh $M$, Sybrecht GW, Schafers HJ, Sester M. Impaired detection of Mycobacterium tuberculosis immunity in patients using high levels of immunosuppressive drugs. Eur Respir J. 2009;34:702-10.

22. Sargın G, Şentürk T, Ceylan E, Telli M, Çildağ S, Doğan H. TST, QuantiFERONTB Gold test and T-SPOT.TB test for detecting latent tuberculosis infection in patients with rheumatic disease prior to anti-TNF therapy. Tuberk Toraks. 2018;66:136-43.

23. Maden E, Bekci T, Kesli R, Atalay H, Teke T, Solak Y,Turk S, Uzun K, Koylu R. Evaluation of performance of quantiferon assay and tuberculin skin test in end stage renal disease patients receiving hemodialysis. New Microbiol. 2011;34:351-6

24. Yilmaz N, Zehra Aydin S, Inanc N, Karakurt S, Direskeneli H, Yavuz S. Comparison of QuantiFERON-TB Gold test and tuberculin skin test for the identification of latent Mycobacterium tuberculosis infection in lupus patients. Lupus. 2012;21:491-5.

25. Qin $L L$, Wang $Q R$, Wang $Q$, Yao $H$, Wen $L T$, Wu LL, Ping NN, Xie JD, Chen MY, Chen SN. T-SPOT.TB for detection of tuberculosis infection among hematological malignancy patients and hematopoietic stem cell transplantation recipients. Asian Pac J Cancer Prev. 2013;14:7415-9.

26. Hasan $T, A u E$, Chen $S$, Tong A, Wong G. Screening and prevention for latent tuberculosis in immunosuppressed patients at risk for tuberculosis: a systematic review of clinical practice guidelines. BMJ Open. 2018;8:e022445.

27. Akan $\mathrm{H}$, Arslan $\mathrm{O}, \mathrm{Akan} \mathrm{OA}$. Tuberculosis in stem cell transplant patients. $J$ Hosp Infect. 2006;62:421-6.

28. Ullah K, Raza S, Ahmed P, Satti TM, Ikram A, Chaudhri QU, Kamal MK, Akhtar FM. Pulmonary tuberculosis in allogeneic stem cell transplant recipients. J Pak Med Assoc. 2007;57:567-9.

29. Herrera V, Perry S, Parsonnet J, Banaei N. Clinical application and limitations of interferon-gamma release assays for the diagnosis of latent tuberculosis infection. Clin Infect Dis. 2011;52:1031-7.

30. Raby E, Moyo M, Devendra A, Banda J, Haas P, Ayles H, Faussett PG. The effects of HIV on the sensitivity of a whole blood IFN-gamma release assay in Zambian adults with active tuberculosis. PLoS One. 2008;3:2489.

31. Çavuşoğlu C, Durusoy R, Yaşar M, Kayın M. Evaluation of QuantiFERON ${ }^{\circledR}$ TB Gold in Tube Test and Tuberculin Skin Test in the Diagnosis of Mycobacterium tuberculosis Infection. Mikrobiyol Bul 2017;51:115-26. 